DOI: $10.52950 / T E .2021 .9 .1 .004$

\title{
GENDERED VISIONS OF IDEAL FUTURE SELVES: AN ANALYSIS OF JAPANESE ENGLISH AS A FOREIGN LANGUAGE LEARNERS' NARRATIVES
}

\section{YOKO MUNEZANE}

\begin{abstract}
:
This study investigates the impact of gender on future visions, using a mixed narrative method; i.e., a "drawing-and-writing-combined" narrative. Previous research shows that learners' career aspirations have a positive effect on their academic achievement including language proficiency growth (Sasaki, Kozaki, \& Ross, 2017). Therefore, it is worthwhile to explore the impact of gender on language learners' future possible selves by examining their career visions. Qualitative data were collected from 155 Japanese university English as a Foreign Language learners' drawings and English essays. Statistical results (chi-square test) revealed gender effects in participants' visualizations of career-focused and career-family balanced ideal selves as well as in the prominence of social interaction in their future visions. Qualitative analysis of participants' essays suggested that the majority of both male and female learners envisaged their future ideal selves actively pursuing an international career empowered by the essential tool of English. Overall, females considered combining family and career as due responsibilities for women, whereas the majority of males envisioned career-related ideal selves only. The study further assesses the impact of gender on learners' future visions by taking into consideration the gender equality level in a particular society. Pedagogical implications and future directions are discussed.
\end{abstract}

\section{Keywords:}

gender differences, possible selves, future visions, classroom-based research, career aspiration

JEL Classification: 129

\section{Authors:}

YOKO MUNEZANE, Rikkyo University, Japan, Email: yokomunezane@rikkyo.ac.jp

\section{Citation:}

YOKO MUNEZANE (2021). GENDERED VISIONS OF IDEAL FUTURE SELVES: AN ANALYSIS OF JAPANESE ENGLISH AS A FOREIGN LANGUAGE LEARNERS' NARRATIVES. International Journal of Teaching and Education, Vol. IX(1), pp. 49-65., 10.52950/TE.2021.9.1.004 


\section{Introduction}

As a social construct, gender surpasses individuals' physiological and biological attributes. Thus it has a symbolic meaning, entailing expectations and obligations in a particular sociocultural context. These gendered norms are assumed to function as templates for how individuals behave, develop their identities, create future visions, and communicate with each other (Knobloch-Westerwick, Kennard, Westerwick, Willis, \& Gong, 2014).

The purpose of the present study is to explore learners' future visions through analyzing their drawings and essays of their visualized futures and career aspirations. Previous research shows that learners' career aspirations have a positive effect on their language proficiency growth (Sasaki, Kozaki, \& Ross, 2017) and that the impact of normative career aspirations on language proficiency growth was more salient among females (Kozaki, \& Ross, 2011). Therefore, it is meaningful to explore the impact of gender on learners' future possible selves by examining their career visions, and how their career visions may influence their envisaged family life, which would influence learner motivation and achievement in language classes. However, future visions are difficult to capture, and one viable measure to approach learners' future visions is by analyzing their drawings and essays, which offer detailed and vivid descriptions of their visualized possible futures. A qualitative exploration of gender differences in the language learner's future visions seems to be still extremely scarce in the published studies in the main journals. This study aspires to make a unique contribution to the field by examining language learners' future visions using a mixed narrative method; i.e., a "drawingand-writing-combined" narrative. It further assesses the impact of gender on learners' future visions by taking into consideration gender equality level in a particular society, since the emergence of future visions and goals in the personal development of individual learners is closely related to the socio-cultural environment.

\section{Literature review}

\subsection{Gender Roles and Self-Construals}

The concept of gender goes beyond individuals' biological and physiological attributes, and generally refers to the interpretation of what it means to be a man or woman in a particular sociocultural context. Therefore, gender roles entail gendered social norms, commonly shared by members of society (Knobloch-Westerwick et al., 2014). In describing individuals' relation to the social world, Bakan (1966) proposed agency and communion as two orientations underlying human existence, suggesting that in general, males exhibit agentic behaviors, prioritizing individuation, uniqueness, and autonomy; whereas females generally adopt communal behaviors, prioritizing the maintenance of social relationships.

Similarly, Markus and Kitayama (1991) proposed the theory of divergent self-construals, specifying independent self-construal and interdependent self-construal. The former features 
an autonomous and unitary self, separate from the social context, characterized by individual abilities, desires, and control over one's surroundings, whereas the latter is defined by connections with social context, as one's relationships with others are key components in construal of the self.

Building on Markus and Kitayama's (1991) study, Cross and Madson (1997) maintained that men tend to develop independent self-construals, whereas women lean towards interdependent-self construals. Regarding sources of self-esteem, women's self-esteem mainly comes from maintaining and enhancing social relationships (Moran \& Eckenrode, 1991). In contrast, men's self-esteem derives, at least partly, from the perceived ability to maintain autonomy and independence (Josephs, Markus, \& Tafarodi, 1992). The self is a cultural and social construction and has been created through experiences with gendered social expectations, norms, and values, as well as the self's responses to gendered situations (Cross \& Madson, 1997). Therefore, the independent versus interdependent gendered self-construal may become less distinct as increasing opportunities have been created for women to be independent, agentive, competitive, wielding power in some hitherto forbidden arenas such as business (Cross \& Madson, 1997; Offerman \& Gowing, 1990).

\subsection{Gender Roles and Future Possible Selves}

The concept of possible selves "represents individuals' ideas of what they might become, what they would like to become, and what they are afraid of becoming" (Markus \& Nurius, 1986). Possible selves are the future view of self and a means to capture dynamics of the self. Imagined possible selves ignite motivation to move toward personally valued goals and aspirations while avoiding negative consequences (Knox, 2006). The greater clarity in envisioning one's future possible self leads to higher levels of positive psychological states such as optimism (McElwee \& Haugh, 2009).

As males and females develop divergent self-construals (Cross \& Madson, 1997), gender differences have been revealed in the construction and development of possible selves (Anthis, Dunkel, \& Anderson, 2004; Knox, 2006). Female self-esteem is found to relate to social competence and interpersonal relationships, thus females are more likely to formulate a repertoire of possible selves, integrating "understanding of others' views of the self." (Knox, 2006, p. 61). In contrast, male self-esteem is related to uniqueness and superiority to others (Goethals, Messick, \& Allison, 1991; Joseph, Markus, and Tafarodi, 1992; Knox, 2006). Therefore, males tend to develop ideal possible selves as uniquely superior to others (Josephs, Markus, \& Tafarodi, 1992; Knox, 2006).

Moreover, previous research (e.g., Segal, DeMeis, Wood \& Smith, 2001) demonstrates that when envisioning the future, females tend to focus on interpersonal issues such as family issues and interpersonal conflicts, whereas males are likely to emphasize goal achievement and agency. Therefore, it was hypothesized that female participants' possible future selves 
might feature more attributes of social interaction such as children and family, compared to their male counterparts, whereas male participants' possible selves were expected to feature agentic actions and career goal pursuits.

\subsection{Gender Differences in Language-related Future Possible Selves (Ideal L2 Self: Quantitative Studies)}

Ideal L2 Self is the L2-specific facet of one's future ideal self, belonging to global 'imagined community' (Norton, 2001) with personal agreeableness and professional success, and is the essential component of Dörnyei's (2005) L2 Motivational Self System. Studies on gender differences in ideal $\mathrm{L} 2$ selves and possible-selves paradigm have consistently revealed higher scores among female participants (Ryan, 2009; Henry, 2009, Kim \& Kim, 2011). Regarding the relationship between learners' career aspiration and language achievement, previous research shows that learners' career aspirations have a positive effect on their language proficiency growth (Sasaki, Kozaki, \& Ross, 2017), and that the impact of normative career aspirations on language proficiency growth was more salient among females (Kozaki, \& Ross, 2011). In the current study, the impact of gender on language learners' future visions including career aspirations will be qualitatively explored.

\subsection{Gender Gap and Future Visions}

Concerning gender equality, Japan lags behind many countries, as the Global Gender Gap Report 2020 (World Economic Forum) indicated that Japan ranked $121^{\text {st }}$ out of 153 countries, based on four indicators-economic participation and opportunity, educational attainment, health and survival, and political empowerment. This low gender equality might result in a shortage of active career women as inspiring role models for female youths in Japan.

Future visions and ideal self-images emerge in the personal development of an individual in his/her interactions with the sociocultural context (Cantor \& Kilhstrom, 1987). Factors in the sociocultural context such as peers, school, home, and the media (Knobloch-Westerwick et al., 2014) contribute to the construction of a personal value system (Kilby, 1993), and influence knowledge about what is possible in the future (Maehr \& Braskamp, 1986). These "values and knowledge of possibilities" (Miller \& Brickman, 2004, p. 14) are the main contributors to the formation and development of possible selves and future visions (Miller \& Brickman, 2004). According to Bandura (1997), self-efficacy beliefs are constructed from mastery experiences, vicarious experiences, social persuasions, and physiological states. Among these four sources, social persuasions and vicarious experiences have been found to have a stronger impact on female students' academic self-efficacy beliefs than on their male counterparts' in some studies (Anderson \& Betz, 2001; Lent, Lopez, Brown, \& Gore, 1996; Zeldin \& Pajares, 2000). Moreover, vicarious experiences; whether students can find the role models in the real society or not, have been found to have a strong influence on female students' self-regulated learning and performance (Bussey, 2011). It is thus likely that social influences from the immediate 
environment such as parents, peers, teachers, mass media, and the overall gender equality level seem to have a great general impact on female learners' self-efficacy beliefs and future visions.

\subsection{5 Purpose of the Study and Research Questions}

The purpose of the present study is to explore the gender differences in learners' future visions and career aspirations, through analyzing their drawings and essays. Based on the review of previous studies on gender differences in identities and future visions, the following research questions are raised: RQ1: How do male and female English as a Foreign Language (EFL) learners envisage their future ideal selves in the language classroom? Are male learners more career-focused compared to females? Q2: Is there any gender difference in learners' future visions, regarding social interactions? In line with the previous research, hypothesis 1 predicts that male participants' future visions are more career-focused than female participants' future visions. Hypothesis 2 predicts that female participants' future visions are more likely to include social interactions.

\section{Methods}

\subsection{Participants}

Participants of this study included 155 first-year and second-year humanity major students enrolled in EFL courses at a university in Tokyo area. They were majoring in international economics, politics, and intercultural communication. Among a total of 155 participants, there were 68 first-year students (43.9\%) and 87 second-year students (56.1\%). There were 89 female participants $(57.4 \%)$ and 66 male participants (42.6\%). Participants' English proficiency levels ranged from basic to advanced. The distribution of participants is shown in Table 1.

Table 1. Distribution of Participants

\begin{tabular}{llll} 
& Female & Male & Total \\
\hline Freshmen & 39 & 29 & 68 \\
Sophomore & 50 & 37 & 87 \\
Total & 89 & 66 & 155 \\
\hline
\end{tabular}

\subsection{Procedure}


To explore the effects of gender on participants' unfolding future visions, qualitative data were collected using visualization worksheets. After a short introduction to visualization, participants were asked to imagine their ideal future selves in 15-20 years pursuing their future careers and were asked to share their visions in pairs using English. For this study, learners were expected to focus on ideal future selves, for educational purposes because previous research shows that envisioning positive future selves leads to higher academic achievement and higher task persistence (Leondari, Syngollitou, \& Kiosseoglou, 1998). Then each was given a worksheet with space provided for the participant to draw a picture. The Prompt was:" Let's imagine the possible future day, 15-20 years from now, how would you be self-actualizing yourself in your career? Possibly using English? Draw a little picture and explain it to your partner!" Learners in groups shared their visions by sharing their drawings. At home, they wrote an English essay to further illustrate their visualization. Students' essays were reported verbatim in this paper. Pseudonyms were used to ensure participant confidentiality. Before conducting the research ethical clearance was granted by asking the participants to sign the consent form.

\subsection{Strength of "mixed" narrative}

The previous study underscored the merit of the story-writing narrative method, as it is advantageous for collecting rich data and more successful in shedding light on the ideal possible selves of the participants, compared to traditional methods such as interview and questionnaire (Whitty, 2009). In the current study, the "mixed" narrative method; i.e., a "drawing-and-writing-combined" narrative, was applied to explore Japanese EFL learners' ideal future selves in greater depth. Drawings and pictures are useful tools for understanding the diverse future dreams and hopes of participants (Berg, Bowen, Smith \& Smith, 2017). Story-telling through visuals is a powerful research tool to get insight into participants' motivation, goals, and visions (Berg, Bowen, Smith \& Smith, 2017). Moreover, the visual narrative provides a friendly scaffold for sharing personal thoughts and experiences (Berg, Bowen, Smith \& Smith, 2017). Another rationale for using a "mixed" narrative is that through collecting the qualitative data from multiple sources, the possible proficiency bias of the participants was expected to be complemented by their drawings.

\subsection{Data Analysis}

For the qualitative data analyses, thematic analyses (Braun \& Clarke, 2006) were performed on the data collected from visualization activity worksheets. In the thematic analysis, data can be analyzed in either an inductive way or in a theoretical, deductive way. In this study, "theoretical thematic analysis" (Braun \& Clarke, 2006, p. 12) was employed to code for specific themes to explore the impact of gender on participants' future visions. In line with the literature review, the data were coded for career and social interaction, which were included as two of 
the six thematic domains for analysis of possible selves in Unemori, Omorgie, \& Markus (2004) study.

After a preliminary data inspection, two additional categories emerged as salient features among the participants. These domains were family, and visions towards aspects other than career and family. The subsequent analysis yielded four categories related to career, including career-focused (aspirations towards career-related hopes and dreams), family-focused (aspirations with a clear emphasis on family life), career-family balanced (aspirations towards a balance between career and family life), and others (aspirations towards aspects other than career and family). Learners' essays and drawings were coded and counted by the researcher, and then independently by a research assistant who was blind to the research hypothesis. Coding categories and examples of coding were thoroughly discussed with a research assistant and ambiguities and disagreements were resolved before the actual coding session. The average interrater agreement was .97.

For the quantitative data analysis, Chi-square tests were performed to assess gender differences in participants' future visions. The revealed gender differences during the quantitative analysis informed qualitative analysis of participants' essays and drawings, which were interpreted with reference to attributes of agency and communion (Bakan, 1996), as well as independent and interdependent self-construals (Markus \& Kitayama, 1991; Cross \& Madson, 1997).

\section{Results}

\subsection{Quantitative Analysis Results}

A one-sample chi-square test was conducted to assess whether male and female participants have differential future visions, regarding family and career. Regarding future vision with career-focused ideal self (career-only), the results of the test were significant, $\mathrm{X}^{2}(d f=1, n=$ $155)=15.79, p<.001$. The results suggested that the proportion of male participants who focused on career-only future selves were significantly larger than that of females. Effect size (Cramer's $V=.32$ ) was medium. Concerning family-focused ideal future self (family-only), the results of the test were not significant, $X^{2}(d f=1, n=155)=3.28, p=.070$, indicating that the proportion of female participants who focused on family-only future selves were not significantly larger than that of males. Regarding future visions, focusing on both career and family, the results of the test were significant, $x^{2}(d f=1, n=155)=12.18, p<.001$, demonstrating that the proportion of female participants who focused both on career and family as their ideal future selves were significantly larger than that of males. Effect size (Cramer's $\mathrm{V}$ $=.28$ ) was medium. Concerning future visions other than career and marriage, the results of the test were not significant, $\mathrm{X}^{2}(d f=1, n=155)=2.06, p=.15$, suggesting that the proportion of males and females who envisioned their future selves other than family and/or career were not significantly different. 
Next, a one-sample chi-square test was conducted to assess whether males and females presented differential future visions concerning interpersonal qualities. The results of the test were significant, $\mathrm{X}^{2}(d f=1, n=155)=15.04, p=.000$, indicating that the proportion of female participants who integrated social interactions in their future visions were significantly larger than that of males. Effect size (Cramer's $V=.31$ ) was medium.

\subsection{Findings from Narrative Data Analysis}

The majority of both male and female participants $-56.1 \%$ of females (50 out of 89 ) and $54.5 \%$ of males (36 out of 66) -visualized their ideal future selves actively working in an international arena, where English skills are essential for living and traveling abroad. Many participants expressed a strong desire and determination to put more effort into learning English. Dream jobs for male participants who aspired towards an international career included an international businessman, the president of an international company, an investor in foreign markets, etc., whereas female participants dreamt of becoming a journalist, a United Nations employee, a travel agent, a cabin attendant, an interpreter, etc. Male participants who visualized pursuing a local career in Japan expressed interest in becoming a teacher, a musician, an office worker, etc., while desired careers among female participants included an English teacher, a translator in a local company, a librarian, a local shop owner, etc. Many students, especially those with aspirations towards an international career wrote in their essay that they needed language skills including English to be successful in their careers and to enjoy traveling abroad. For example, a female student, Aya, visualized herself living and working abroad using multiple languages:

In 15 to 20 years from now, which means when I become 34 to 39, I think I will live in Germany or the UK with dogs or cats and work so hard there, using many languages, such as English, French, German and so on. I hope I will be using the knowledge of international politics or relations that I'm studying right now in order to make the world a better place. I also hope that I will be traveling to many countries, and most importantly, living a happy life! (Aya)

Aya's visualized ideal self was someone living in multilingual Europe, exploiting her expertise in international politics. Along with several other students (both males and females), she expressed her altruistic wish to contribute to a better future for humanity by making meaningful use of school knowledge. Aya ended her essay with a personal wish to live a happy life.

Envisaging himself as a global person living in Hawaii, a male student, Taka, mentioned how English skills would matter to him:

My dream is to live in Hawaii. .... But it is necessary for me to get English skills to realize my dream. So I would like to try hard in studying [English] as well as everything else from now on as well. I want to be a global man. (Taka)

Realizing the importance of English skills in achieving his dreams as well as the value of other subjects, Taka expressed his determination to put effort into academic studies. 
In line with the quantitative results which indicated a significant gender effect on careerfocused and career-family balanced future visions, more than twice as many male participants only had visions of their career-related ideal selves as female participants ( $56.1 \%$ vs. $24.7 \%$ ). In contrast, close to $45 \%$ (40 out of 89 ) of female participants envisaged both career-related and family-related ideal selves, whereas only $18.2 \%$ (12 out of 66 ) of male participants envisaged both (Table 2).

Many female participants seemed to assume that they are supposed to combine motherhood and career pursuit, managing household chores and parenting tasks while pursuing a career of their choice. For example, Eri envisaged her ideal self as a dedicated employee, while taking care of all the housework and her children. Eri wrote:

...In 20 years in the future, I want to be a woman who handle[s] both a business work and housework. At a company, l'll work as [like] a man and make an achievement. At my house, I'll do all [the] house work and the job of raising my children. I want to be both [a] career woman and [a] good mom and wife.....Sometimes, I want to play the piano. Probably it will refresh my spirit. (Eri)

Eri's ideal future self was a multiple-role woman who aspires to achieve her career goals, as well as to be a perfect mom and wife, juggling a family and a career.

On the other hand, several other female participants expressed doubts about the compatibility of family life with a career. For example, Miku expressed her hesitation over pursuing a career as well as to spend time with her children. Miku wrote:

In the future day, 15 to 20 years from now, I hope I [will] have my children and spend my time with children as [the] same as my mother did for me. Of course, I would like to work a little. So if I have enough time for my career, maybe I will work. However, the order of priority is that first is my family and second is myself [my career]. (Miku)

In this excerpt, Miku expressed her wish to have her own career if possible; however, evoked childhood memories of her mother led to the decision that she would prioritize raising children if she did not have enough time for both.

By contrast, several male participants considered a successful career and a married life to be mutually exclusive. For example, Syun wrote:

After 20 years, I still wouldn't get married to anyone because I will be busy with my work. Moreover, I will be a globetrotter, so I make many friends around the world. I feel that I live a full life every day. Although I am finding out [seeking] the pleasure in a side of business [on the business side], a side of marriage [the marriage side] will be difficult for me. To be compatible with [combine] business and love is so hard. (Syun)

In this excerpt, Syun envisioned his future self as an international businessman. He deemed it impossible to have a family while focusing on achieving career goals, thus portraying his future image as a bachelor who derived joy from work. 
Another marked difference in line with the quantitative results was that overall social interaction was found to be a more prominent theme in female participants' depictions of future ideal selves than in those of male participants. Analysis of participants' essays showed that nearly $90 \%$ of female participants (78 out of 90 ) drew the picture of themselves in social interaction settings, and/or wrote an essay describing the scene, using words and phrases such as "friends," "relationship," "talking to people from abroad," "playing with children," and "communicating with people." On the other hand, $56.1 \%$ of male participants (37 out of 68) drew the picture of themselves in social interactions and/or used related words and phrases in their essays. This finding was further evidenced by female participants' drawings. For example, one picture featured the participant communicating with three foreigners in English at the center, with temples, Mt. Fuji, Japanese Hina dolls, and national flags of three different countries in the background, illustrating her ideal self, as a cultural ambassador, introducing Japan to overseas visitors.

Male participants' drawings, on the other hand, typically featured an isolated image, with themselves at the center yet anybody in the surroundings. Analysis of their essays corroborated this finding, as expressions concerning social interaction were largely absent in their narratives. For example, Ken drew a picture of himself calling the shots and confirmed this wish in his essay. Ken wrote:

In the future l'll be [the] president of [a] venture capital [firm]. There are two reasons. First, I'd like to challenge [the old] and open up [try] something new. I have a great enterprise in solving the puzzle. Second [the other] reason is to stick to the proverb, "It's better to be a big fish in a little pond than a little fish in a big pond." I'm self-confident as an ambitious boy, and I'm willing to do hardworking [work hard]. So when I'll be [am] 35 years old, I'm [will rise to] the top of [the] venture capital [firm]. (Ken)

Ken's vision of career-related ideal self was actualized in the president of a venture capital firm. His goal-oriented mindset was evident in expressions such as "l'd like to challenge...," "I'm self-confident...," and "I will be [the] president...," indicative of an agentic self. 
Table 2. Characteristics by Gender: Career and Family

\begin{tabular}{|l|l|l|}
\hline & Male participants & Female participants \\
\hline $\begin{array}{l}\text { Sareer-related ideal future } \\
\text { senly }\end{array}$ & $\begin{array}{l}37(56.1 \%) \text { (e.g.: public } \\
\text { officer, international } \\
\text { business person, president } \\
\text { of a company, film director, } \\
\text { investor, etc.) }\end{array}$ & $\begin{array}{l}22 \text { (24.7\%) (e.g.: journalist, } \\
\text { TV caster, U.N. worker, } \\
\text { travel agent, cabin } \\
\text { attendant, interpreter, } \\
\text { translator, shop owner, } \\
\text { etc.) }\end{array}$ \\
\hline $\begin{array}{l}\text { Family-related ideal future } \\
\text { selves only }\end{array}$ & $8(12.1 \%)$ & $21(23.6 \%)$ \\
\hline $\begin{array}{l}\text { Both Career-related and } \\
\text { Family-related ideal future } \\
\text { selves }\end{array}$ & $12(18.2 \%)$ & $40(44.9 \%)$ \\
\hline $\begin{array}{l}\text { Others (e.g.: traveling } \\
\text { around the world) }\end{array}$ & $9(13.6 \%)$ & $6(6.7 \%)$ \\
\hline TTL & 66 & 89 \\
\hline
\end{tabular}

\section{Discussion}

Overall, the results suggest a positive answer to the research question, confirming gender differences in EFL learners' envisioned ideal future selves in the language classroom. The majority of both male and female participants envisioned their ideal future selves pursuing an international career facilitated by English. Therefore, many students expressed their strong wish and determination to put more effort into English study to realize their future dreams.

Concerning gender differences, the overall results indicate female participants tended to consider combining work and family responsibilities with caring spirit as a due role for women. On the other hand, male participants tended to focus solely on career-related ideal self, and some regarded building a successful career and having a married life as mutually exclusive. This vision seems to put further strain on women juggling a career and a family, as men singlemindedly expect to concentrate their efforts on fulfilling career goals and job obligations (Barker, 1993). Many female participants envisaged a possible dilemma of balancing commitments to work and family. To some extent, this shared work-family dilemma hints at the fact that a substantial number of Japanese women today still have to give up their careers for family duties and child-rearing after marriage due to childcare shortages (Oi, 2015). This situation is compounded by the remaining gender gap, which may have made it difficult for female students to find role models in real life, (Bussey, 2011). This current situation might lead to 
gender differences in the effectiveness of classroom activities such as future visualization which is designed to enhance student motivation and achievement and to prepare students for the future, through connecting classrooms to the real world (Munezane, 2015). If females cannot envisage their career aspirations in realistic terms, that might potentially affect their commitment to the classroom activities, concerning goals in their future career.

In their visualization activity worksheet (drawing and essay), female participants comprised more pictures of themselves interacting with other people and devoted more words and expressions to social interactions in their short essays than male participants. They also integrated others' expectations, including their future children's expectations in forming their ideal future selves, as shown in the female participant, Miku's essay. The social expectations for women to take care of family and children may have contributed to their perception of women as double-tasked with family care and career pursuit. On the other hand, male participants' ideal future selves were dominantly characterized by career goal-seeking, leadership, ambition, and agentic actions. These revealed gender differences in ideal-self and future visions were consistent with the established interdependent versus independent selfconstrual divide between women and men (Cross \& Madson, 1977).

\section{Conclusions}

The limitation of the study is that since the ideal-future-visualization activity was mainly conducted in English, there is a possibility that language proficiency has influenced participants' essays. Chances are that lower-proficiency students were not able to describe their future visions as clearly and accurately as their higher-proficiency counterparts. Hence their future visions in their essay might not do full justice to their visualized futures, though their drawings may have complemented their lack of proficiency. Despite this limitation and others such as sample size and diversity, which possibly limits the generalizability of the findings, this study has revealed some important gender differences in EFL learners' future visions. Based on the results obtained in this study, I would like to suggest some practical pedagogical implications and future directions and conclude the study.

Increasing female labor force participation is one of the policy targets in the structural reforms implemented by the Japanese government (Japan Revitalization Strategy, 2014). Over time, it is expected that the possible expansion of women's participation in all fields of life and the narrowing gender gap would foster similar expectations career aspirations in male and female students. Moreover, female students would expect to envision their future ideal selves as active career women by gaining vicarious experiences and motivation from real-life women role models. Thus it would be of interest to conduct a longitudinal study to explore the impact of policy changes on gender differences in learners' future visions.

The potential family-career balance dilemma confronting Japanese students might be shared among youths in East Asia, the United States, European countries, and elsewhere in the world. 
Recently studies conducted in the workplace in China, Iceland, and other parts of the world have revealed that work-family conflict influences female employees' career development (Acker, 2009; Júlíusdóttir, Rafnsdóttir, \& Einarsdóttir, 2018; Rasheed, lqbal, \& Mustafa, 2018; Tlaiss, \& Kauser, 2011; Wang \& Cho, 2013). Hence a cross-cultural comparative study might be of interest. Furthermore, the steady progress of globalization leads to an increasingly multicultural and multilingual world. This unstoppable trend makes language classrooms one of the best places for learners to start thinking about their ideal future role in a globalizing world. With opportunities to express their opinions freely and generate ideas for their fruitful and achievable futures, learners can envisage and strive for their ideal selves.

EFL teachers are encouraged to experiment with activities such as individual conferences and small group conferences in designing activities to promote entrepreneurship (Aljonani, 2015; Finnish Ministry of Education, 2004; European Commission, 2004; Komulainen, Korhonen, \& Räty, 2009; Proskunina, Moehring, Schneider, \& Storch, 2019), for example, in language classrooms. These activities would provide students with opportunities to share their observations and perceptions of social change, which might help students define and articulate their visions and take a real look at their future selves, through connecting their current self to their adult possible future self (Nurra \& Oyserman, 2018). It is also advisable to invite real-life role models such as professionals pursuing an international career using English as an opportunity for students to gain vicarious experiences, which would help them visualize their future careers using English. These activities could be effective for both males and females, as research shows the significant impact of social persuasion (Usher \& Pajarers, 2006) and vicarious experience (Bussey, 2011) on academic self-efficacy and self-regulated learning respectively for females and the significant impact of vicarious experience on self-efficacy for males (Usher \& Pajares, 2006).

To realize their future dreams and ideal selves, both male and female students expressed their wish and determination to put more effort into learning English and other languages. Future visualization activity contributes to students' recognition of the importance of English as an international communication tool. This points to the possibility that activities such as future visualization in the language classroom can increase learner's motivation and build a positive self-image, connecting the classroom with a possible future. In addition, several students expressed their altruistic wish to contribute to a better future for humanity, along with their egocentric wish to live a happy life. Through sharing their future visions, students could collaboratively enhance their altruistic wish toward the betterment of society, local communities, and family life, which could be integrated into their future personal identities. Language teachers could provide opportunities for students to exchange ideas on how they would like to contribute to the brighter futures for both men and women, in this increasingly globalizing, multicultural world. 


\section{References}

Acker, J. (2009). From Glass Ceiling to Inequality Regimes. Sociologie du Travail, 51 (2), 199-217. https://doi.org/10.4000/sdt.16407

Aljonani, M. (2015). Innovation and Entrepreneurship Integration in Education. Ohio state model. International Journal of Teaching and Education, 3(3), pp. 1-20. DOI: 10.20472/TE.2015.3.3.001

Anderson, S., \& Betz, N. (2001). Sources of social self-efficacy expectations: Their measurement and relation to career development. Journal of Vocational Behavior, 58, 98-117. https://doi.org/10.1006/jvbe.2000.1753

Anthis, K. S., Dunkel, C. S., \& Anderson, B. (2004). Gender and identity status differences in late adolescents' possible selves. Journal of Adolescence, 27(2), 147-152. https://doi.org/10.1016/j.adolescence.2003.11.010

Bakan, D. (1966). The duality of human existence: Isolation and communion in Western man. Boston: Beacon Press.

Bandura, A. (1997). Self-efficacy: The exercise of control. New York: Freeman.

Barker, K. (1993). Changing assumptions and contingent solutions: The costs and benefits of women working full- and part-time. Sex Roles, 28, 47-71. https://doi.org/10.1007/BF00289747

Berg, T., Bowen, T., Smith, C., \& Smith, S. (2017). Visualizing the Future: Surfacing student perspectives on post-graduation prospects using Rich Pictures. Higher Education Research and Development, 36(7), 1339-1354. https://doi.org/10.1080/07294360.2017.1325855

Braun, V. \& Clarke, V. (2006). Using thematic analysis in psychology. Qualitative Research in Psychology 3(2):77-101. https://doi.org/10.1191/1478088706qp063oa

Bussey, K. (2011). The influence of gender on students' self-regulated learning and performance. In B. J. Zimmerman \& D. H. Schunk (Eds.), Handbook of self-regulation of learning and performance: Educational psychology handbook series (pp. 426-441). (Educational Psychology Handbook). Abingdon, UK: Routledge, Taylor \& Francis Group.

Cantor, N., \& Kihlstrom, J. F. (1987). Personality and Social Intelligence. Englewood Cliffs, NJ: PrenticeHall.

Cross, S. E., \& Madson, L. (1997). Models of the self: Self-construals and gender. Psychological Bulletin, 122(1), 5-37. https://doi.org/10.1037/0033-2909.122.1.5

Dörnyei, Z. (2005). The psychology of the language learner: Individual differences in second language acquisition. New York, NY: Routledge.

Dörnyei, Z. (2009). The L2 motivational self system. In Z. Dörnyei \& E. Ushioda (Eds.), Motivation, language identity and the L2 self (pp. 9-42). Bristol, England: Multilingual Matters. https://doi.org/10.21832/9781847691293-003

European Commission. 2006. Entrepreneurship action plan. Key action sheets Key action 1 - Fostering entrepreneurial mindsets through school education. http://ec.europa.eu/enterprise/entrepreneurship/action plan/index.htm (accessed December 2020) 
Finnish Ministry of Education. 2004. Policy for entrepreneurship education. Publications of the Ministry of Education, no. 18, Helsinki: Ministry of Education. http://www.minedu.fi/export/sites/default/OPM/Julkaisut/2004/liitteet/opm 169 opm1 8.pdf?lang=fi (accessed December 2020)

Goethals, G. R., Messick, D. M., \& Allison, S. T. (1991). The uniqueness bias: Studies of constructive social comparison. In J. Suls \& T. A. Wills (Eds.), Social comparison: Contemporary theory and research (pp. 149-176). Hillsdale, NJ: Erlbaum.

Henry, A. (2009). Gender differences in compulsory school pupils' L2 self-concepts: A longitudinal study. System, 37, 177-193. https://doi.org/10.1016/j.system.2008.11.003

Japan Revitalization Strategy. (2014). Japan's challenge for the future. Retrieved from https://www.kantei.go.jp/jp/singi/keizaisaisei/pdf/honbunEN

Josephs, R. A., Markus, H. R., \& Tafarodi, R. W. (1992). Gender and self-esteem. Journal of Personality and Social Psychology, 63, 391-402. https://doi.org/10.1037/0022-3514.63.3.391

Júlíusdóttir, O., Rafnsdóttir, G. L., \& Einarsdóttir, P. (2018). Top managers and gendered interplay of organizations and family life: the case of Iceland. Gender in Management: An International Journal, 33(8), 602-622. https://doi.org/10.1108/GM-03-2017-0028

Kilby, R.W. (1993). The study of human values. New York: University Press of America.

Kim, Y. K., \& Kim, T. Y. (2011). Gender differences in Korean secondary school students' learning styles and L2 motivation. Foreign Languages Education, 18(2), 51-71.

Leondari, A., Syngollitou, E., \& Kiosseoglou, G. (1998). Academic achievement, motivation and future selves. Educational Studies, 24(2), 153-163. https://doi.org/10.1080/0305569980240202

Locke, E. A., \& Latham, G. P. (1990). A theory of goal setting and task performance. Englewood Cliffs, NJ: Prentice-Hall.

Knobloch-Westerwick, S., Kennard, A. R., Westerwick, A., Willis, L. E., \& Gong, Y. (2014). A crack in the crystal ball? Prolonged exposure to media portrayals of social roles affect possible future selves. Communication Research, 41(6), 739-759. https://doi.org/10.1177/0093650213491113

Knox, M. (2006). Gender and possible selves. In C. Dunkel \& J. Kerpelman (Eds.), Possible selves: Theory, research and applications (pp. 61-77). New York: Nova Science.

Komulainen K., Korhonen, M. \& Räty (2009). H. Risk-taking abilities for everyone? Finnish entrepreneurship education and the enterprising selves imagined by pupils. Gender and Education (21), 631-649. https://doi.org/10.1080/09540250802680032

Kozaki, Y. \& Ross, S. (2011). Contextual dynamics in foreign language learning motivation. Language Learning, 61(4), 1328-1354. https://doi.org/10.1111/j.1467-9922.2011.00638.x

Leondari, A. Syngollitou, E. \& Kiosseoglou, G. (1998) Academic Achievement, Motivation and Future Selves, Educational Studies, 24:2, 153-163, DOI: 10.1080/0305569980240202

Lent, R.W., Lopez, F. G., Brown, S. D., Gore, P.A. Jr. (1996). Latent Structure of the Sources of Mathematics Self-Efficacy. Journal of Vocational Behaviour 49(3), 292-308. https://doi.org/10.1006/jvbe.1996.0045 
Maehr, M. L., and Braskamp, L. A. (1986). The Motivation Factor: A Theory of Personal Investment, Lexington Books, Lexington, MA

Markus, H. R., \& Kitayama, S. (1991). Culture and the self: Implications for cognition, emotion, and motivation. Psychological Review, 98(2), 224-253. https://doi.org/10.1037/0033-295X.98.2.224

Markus, H. R., \& Nurius, P. (1986). Possible selves. American Psychologist, 41(9), 954-969. https://doi.org/10.1037/0003-066X.41.9.954

McElwee, R. O. \& Haugh, J. A. (2010). Thinking Clearly Versus Frequently About the Future Self: Exploring This Distinction and its Relation to Possible Selves, Self and Identity 9(3), 298-321. https://doi.org/10.1080/15298860903054290

Miller, R. B., \& Brickman, S. J. (2004). A model of future-oriented motivation and self-regulation. Educational Psychology Review, 16(1), 9-33. https://doi.org/10.1023/B:EDPR.0000012343.96370.39

Moran, P. B., \& Eckenrode, J. (1991). Gender differences in the costs and benefits of peer relationships during adolescence. Journal of Adolescent Research, 6(4), 396-409. https://doi.org/10.1177/074355489164002

Munezane, Y. (2015). Enhancing willingness to communicate: Relative effects of visualization and goalsetting. The Modern Language Journal, 99(1), 175-191. https://doi.org/10.1111/modl.12193

Norton, B. (2001). Non-participation, imagined communities and the language classroom. In M. Breen (Ed.), Learner contributions to language learning: New directions in research (pp. 159-171). Harlow, UK: Pearson Education.

Nurra, C. \& Oyserman, D. (2018). From future self to current action: An identity-based motivation $\begin{array}{lllll}\text { perspective. Self and Identity, } & \text { 17(3), }\end{array}$ https://doi.org/10.1080/15298868.2017.1375003

Oi, M. (2015, March 10). Japanese women at a crossroads. BBC News Online. Retrieved from www.bbc.com/news/business-31792714

Ryan, S. (2009). Self and identity in L2 motivation in Japan: The ideal I2 self and Japanese learners of English. In Z. Dörnyei \& E. Ushioda (Eds.), Motivation, language identity and the L2 self (pp. 120143). Bristol, England: Multilingual Matters. https://doi.org/10.21832/9781847691293-007

Proskunina, U., Moehring, J., Schneider, K., Storch, M. (2019). Training female entrepreneurs: a selfgoverned or tutor-driven learning process? International Journal of Teaching and Education, 7(1), pp. 73-91. , DOI: 10.20472/TE.2019.7.1.006

Rasheed, M., Iqbal S, Mustafa, F. (2018). Work-family conflict and female employees' turnover intentions. Gender in Management: An International Journal, 33(8), 636-653. https://doi.org/10.1108/GM-09-2017-0112

Sasaki, M., Kozaki, Y., \& Ross, S. (2017). The impact of normative environments on learner motivation and L2 reading ability growth. The Modern Language Journal, 101(1), 163-178. https://doi.org/10.1111/modl.12381 
Segal, H.G., DeMeis, D. K., Wood, G. A., \& Smith, H. L. (2001). Assessing future possible selves by gender and socioeconomic status using the Anticipated Life History measure. Journal of Personality, 69(1), 57-87. https://doi.org/10.1111/1467-6494.00136

Tlaiss, H. and Kauser, S. (2011). The Impact of Gender, Family, and Work on the Career Advancement of Lebanese Women Managers. Gender in Management: An International Journal, 26 (1), 8-36. https://doi.org/10.1108/17542411111109291

Unemori, P., Omoregie, H. \& Markus, H. R. (2004) Self-Portraits: Possible Selves in EuropeanAmerican, Chilean, Japanese and Japanese- American Cultural Contexts, Self and Identity, 3:4, 321- 338, DOI: 10.1080/13576500444000100

Usher, E. L., \& Pajares, F. (2006). Sources of academic and self-regulatory efficacy beliefs of entering middle school students. Contemporary Educational Psychology, 31(2), 125-141. https://doi.org/10.1016/j.cedpsych.2005.03.002

World Economic Forum. (2020). Global gender gap report 2020. Retrieved from http://www3.weforum.org/docs/WEF GGGR 2020.pdf

Wang, W., \& Cho, T. (2013). Work-family conflict influences on female's career

development through career expectation. Journal of human resource and sustainability studies, 43-50.

Whitty, M. (2009). Possible selves: An exploration of the utility of a narrative approach. Identity: An International Journal of Theory and Research, 2(3), 211-228. https://doi.org/10.1207/S1532706XID0203_02

Zeldin, A. L., \& Pajares, F. (2000). Against the Odds: Self-Efficacy Beliefs of Women in Mathematical, Scientific, and Technological Careers. American Educational Research Journal 37(1), 215-246. https://doi.org/10.3102/00028312037001215 